\title{
46,XX testicular disorder of sexual development with $S R Y$-negative caused by some unidentified mechanisms: a case report and review of the literature
}

Tian-Fu Li ${ }^{1 \dagger}$, Qiu-Yue Wu ${ }^{1+}$, Cui Zhang ${ }^{1}$, Wei-Wei Li ${ }^{1}$, Qing Zhou' ${ }^{1}$, Wei-Jun Jiang ${ }^{1}$, Ying-Xia Cui ${ }^{1}$, Xin-Yi Xia ${ }^{1 *}$ and $\mathrm{Yi}$-Chao $\mathrm{Shi}^{2^{*}}$

\begin{abstract}
Background: $46, \mathrm{XX}$ testicular disorder of sex development is a rare genetic syndrome, characterized by a complete or partial mismatch between genetic sex and phenotypic sex, which results in infertility because of the absence of the azoospermia factor region in the long arm of $Y$ chromosome.

Case presentation: We report a case of a 14-year-old male with microorchidism and mild bilateral gynecomastia who referred to our hospital because of abnormal gender characteristics. The patient was treated for congenital scrotal type hypospadias at the age of 4 years. Semen analysis indicated azoospermia by centrifugation of ejaculate. Levels of follicle-stimulating hormone and luteinizing hormone were elevated, while that of testosterone was low and those of estradiol and prolactin were normal. The results of gonadal biopsy showed hyalinization of the seminiferous tubules, but there was no evidence of spermatogenic cells. Karyotype analysis of the patient confirmed 46,XX karyotype and fluorescent in situ hybridization analysis of the sex-determining region $Y$ (SRY) gene was negative. Molecular analysis revealed that the SRY gene and the AZFa, AZFb and AZFc regions were absent. No mutation was detected in the coding region and exon/intron boundaries of the RSPO1, DAX1, SOX9, SOX3, SOX10, ROCK1, and DMRT genes, and no copy number variation in the whole genome sequence was found.

Conclusion: This study adds a new case of SRY-negative 46,XX testicular disorder of sex development and further verifies the view that the absence of major regions from the $Y$ chromosome leads to an incomplete masculine phenotype, abnormal hormone levels and infertility. To date, the mechanisms for induction of testicular tissue in 46, $X X S R Y$-negative patients remain unknown, although other genetic or environmental factors play a significant role in the regulation of sex determination and differentiation.
\end{abstract}

Keywords: 46,XX testicular disorder of sex development, Ambiguous genitalia, SRY-negative

\footnotetext{
*Correspondence: xinyixia78@gmail.com; yichaoshi71@gmail.com

${ }^{\dagger}$ Equal contributors

'Department of Reproduction and Genetics, Institute of Laboratory Medicine,

Jinling Hospital, Nanjing University School of Medicine, Nanjing 210002, PR

China

${ }^{2}$ Center for Reproduction and Genetics, Suzhou Municipal Hospital, Nanjing

Medical University Affiliated Suzhou Hospital, 26 Daoqian Street, Suzhou

215002, PR China
}

C Biomed Central (c) $2014 \mathrm{Li}$ et al.; licensee BioMed Central. This is an Open Access article distributed under the terms of the Creative Commons Attribution License (http://creativecommons.org/licenses/by/4.0), which permits unrestricted use, distribution, and reproduction in any medium, provided the original work is properly credited. The Creative Commons Public Domain Dedication waiver (http://creativecommons.org/publicdomain/zero/1.0/) applies to the data made available in this article, unless otherwise stated. 


\section{Background}

46 , XX testicular disorder of sex development (DSD) is a rare genetic syndrome, which is characterized by a complete or partial mismatch between genetic sex and phenotypic sex [1]. In addition, 46,XX testicular DSD always presents as one of three phenotypes: (1) classic XX males, infertility with normal male internal and external genitalia; (2) XX males with ambiguous genitalia, which is usually apparent at birth by external genital ambiguities, such as hypospadias, micropenis, or hyperclitoridy, and (3) XX true hermaphrodites with internal or external genital ambiguities detected at birth [2-4]. The sexdetermining region $\mathrm{Y}(S R Y)$ gene plays a major role in encoding a testis determining factor (TDF), which is located on the Y chromosome [5,6]. Approximately $80 \%$ of patients with 46,XX testicular DSD are $S R Y$-positive and usually have a normal male phenotype at birth. Other $S R Y$-negative 46,XX males exhibit different degrees of masculinization [7]. However, even though 46,XX males carry different phenotypes, these patients are often infertile because of the absence of the AZFa, AZFb and AZFc regions [8].

Here, we analyzed the clinical characteristics, chromosomal karyotype, and related genes in a male with 46,XX testicular DSD, who referred to our hospital because of abnormal gender characteristics. The aim of the present study was to investigate the different clinical characteristics in different categories of sex reversed 46,XX individuals and the relationships with variable clinical phenotypes and expression levels of the SRY, RSPO1, $D A X 1$, SOX9, SOX3, SOX10, ROCK1, and DMRT genes. We also reviewed the literature to identify proposed mechanisms to explain the etiology of $S R Y$-negative 46,XX sex reversal (Table 1$)$.

\section{Case presentation}

\section{Participant and clinical data}

A 14-year-old male with microorchidism and mild bilateral gynecomastia was referred to our outpatient clinic because of abnormal gender characteristics. A physical examination included measurement of height, assessment of potential gynecomastia, and inspection of the external sex organs. Bilateral volume was calculated as the sum of the volume of both testes. Semen analysis was assessed according to the guidelines of the World Health Organization. Serum levels of follicle-stimulating hormone (FSH), luteinizing hormone (LH), estradiol (E2), prolactin (PRL), and testosterone $(\mathrm{T})$ were also assessed.

\section{Methods}

Histopathological examination of gonadal tissue

A gonadal biopsy was performed and specimens were obtained, sliced into $4 \mu \mathrm{m}$-thick histological sections, and stained with hematoxylin-eosin (HE) for microscopic analysis [9].

\section{Immunohistochemical staining of gonadal tissue for inhibin and vimentin}

Gonadal tissue from the patient was fixed in $10 \%$ buffered formalin solution, embedded in paraffin, and sliced into 3- $\mu \mathrm{m}$ sections for immunostaining with monoclonal antibodies against inhibin and vimentin (HZ817454; dilution, 1:400; Enzyme Chain Biotechnology Co., Ltd., Shanghai, China). The tissue sections were dewaxed and subjected to antigen retrieval (pressure cooking for 1 min, 15 psi, in $0.001 \mathrm{M}$ EDTA, pH 8.0). Immunohistochemical staining of inhibin and vimentin was performed using the EnVision ${ }^{\mathrm{Tm}}+$ System (K5007; Dako Denmark A/S, Glostrup, Denmark) [9].

Table 1 Milestones of 46,XX testicular DSD

\begin{tabular}{|c|c|c|c|}
\hline Year & Viewpoints & & References \\
\hline 1964 & $46, X X$ testicular DSD was first described. & & Delachapelle et al. [1] \\
\hline 1992 & SRY-positive & $\begin{array}{c}\text { The SRY gene plays a major role in encoding } \\
\text { TDF and indicated that SRY-positive } 46, X X \\
\text { males were infertile. }\end{array}$ & McElreavey et al. [4] \\
\hline \multirow[t]{2}{*}{$2001 ; 2004$} & \multirow[t]{4}{*}{ SRY-negative } & \multirow{2}{*}{$\begin{array}{l}\text { Hidden mosaicism was reported to cause TH } \\
\text { in some } 46, X X S R Y \text {-negative patients, but the } \\
\text { results were differed. }\end{array}$} & Nieto et al. [14] \\
\hline & & & Domenice et al. [15] \\
\hline \multirow[t]{2}{*}{$2008 ; 2011$} & & \multirow{2}{*}{$\begin{array}{l}\text { Up/down regulation of the testis/ovarian } \\
\text { signaling pathways was found. }\end{array}$} & Smith et al. [17] \\
\hline & & & Tomaselli et al. [18] \\
\hline \multirow[t]{6}{*}{ 2010-2013 } & \multirow{6}{*}{$\begin{array}{l}\text { Described the function of the genes } \\
\text { located downstream of the SRY gene. }\end{array}$} & \multirow[t]{6}{*}{ DAX1, SOX9, SOX3, SOX10, ROCK1, DMRT } & Mizuno et al. [13] \\
\hline & & & Sukumaran et al. [23] \\
\hline & & & Moalem et al. [24] \\
\hline & & & Sutton et al. [25] \\
\hline & & & Laronda et al. [26] \\
\hline & & & Polanco et al. [27] \\
\hline
\end{tabular}




\section{Karyotype analysis of G-banding in lymphocytes and fluorescence in situ hybridization (FISH)}

Karyotyping of 100 metaphase lymphocytes from peripheral blood was performed by conventional techniques. The $\mathrm{X}$ chromosome, $\mathrm{Y}$ chromosome, and $S R Y$ gene were located using FISH with probes specific for the centromeres of the $\mathrm{X}$ and $\mathrm{Y}$ chromosomes (item no.: 32-111051CEP X with Spectrum Green and CEP Y with Spectrum Orange; Vysis, Inc., Downers Grove, IL, USA) and SRY gene (item no.: 30-190079, $S R Y$ with Orange; Vysis, Inc.) [10].

\section{Molecular analysis}

Genomic DNA from peripheral blood was extracted using the QIAamp DNA Blood Kit (Qiagen GmbH, Hilden, Germany). Three discrete regions (AZFa, AZFb, and AZFc) located on the long arm of $\mathrm{Y}$ chromosome were amplified by multiplex polymerase chain reaction (PCR) using primers specific for the diagnosis of microdeletion of the AZFa, AZFb, and AZFc regions, which included sY84, sY86, sY127, sY134, sY254, sY255, SRY, and ZFX/ $Z F Y$. Then, the RSPO1, DAX1, SOX9, SOX3, SOX10, $R O C K 1$, and $D M R T$ genes were amplified and sequenced [10]. We also analyzed the presence of SRY sequence in fresh gonadal tissues from this 46,XX male case.

\section{Single nucleotide polymorphism array}

Genomic DNA of the patient was extracted and analyzed using the Cytogenetics Whole-Genome 2.7 M Array (Affymetrix, Inc., Santa Clara, CA, USA), especially for the SOX9 gene, located between $64000 \mathrm{~kb}$ and $72000 \mathrm{~kb}$ on chromosome 17q24.2-25.1, according to the manufacturer's protocols. Briefly, genomic DNA was denatured, neutralized, and then amplified by PCR. The PCR products were then purified, fragmented, and end-labeled with biotin. The fragmented, labeled PCR products were then hybridized overnight to the arrays. The variation in copy number was analyzed using Chromosome Analysis Suite software (v1.2.2; Affymetrix, Inc.) [11].

\section{Ethics statement}

The research adhered to the tenets of the Declaration of Helsinki. The Ethics Committee of Jinling Hospital approved the protocols used in this study. Written informed consent was obtained from the parent of the patient for publication of this case report and any accompanying images. A copy of the written consent is available for review by the Editor of this journal.

\section{Results}

The patient was treated for congenital scrotal type hypospadias at the age of 4 years. On physical evaluation, the patient's weight was $51 \mathrm{~kg}$ (age-appropriate mean weight, $53.37 \pm 9.29 \mathrm{~kg}$ ) and height was $155 \mathrm{~cm}$ (ageappropriate mean height, $165.90 \pm 7.21 \mathrm{~cm}$ ). The grade of gynecomastia was IA [12]. Pubic hair was normal, the length of stretched penile was $3 \mathrm{~cm}$ and bilateral testicular volume was $2 \mathrm{~mL}$. The results of laboratory analysis were as follows: $\mathrm{T}=5.8 \mathrm{nmol} / \mathrm{L}$ (normal range, 9.4-37 nmol/L), E2 $=0.142 \mathrm{nmol} / \mathrm{L}$ (normal range, 0.129$0.239 \mathrm{nmol} / \mathrm{L}$ ), $\mathrm{FSH}=24.4 \mathrm{IU} / \mathrm{L}$ (normal range, 1.5$11.5 \mathrm{IU} / \mathrm{L}$ ), $\mathrm{LH}=15.7 \mathrm{IU} / \mathrm{L}$ (normal range, 1.1-8.2 IU/L), and $\mathrm{PRL}=174.2 \mathrm{mIU} / \mathrm{L}$ (normal range, 89.04-826.8 $\mathrm{mIU} / \mathrm{L})$. Semen analysis by centrifugation of the ejaculate indicated azoospermia and no spermatogenic cells were observed. The levels of seminal plasma fructose, $\alpha$-glucosidase, and acid phosphatase were $2.08 \mathrm{~g} / \mathrm{L}$ (normal range, $0.87-3.95 \mathrm{~g} / \mathrm{L}$ ), $51.93 \mathrm{U} / \mathrm{mL}$ (normal range, 35.1$87.7 \mathrm{U} / \mathrm{mL}$ ), and $12.37 \mathrm{U}$ (normal range, 48.8-208.6 U), respectively.

The gonadal biopsy results showed hyalinization of the seminiferous tubules, but without evidence of spermatogenic cells (Figure 1). Consistent with gonadal biopsy, immunohistochemical analysis also confirmed that the gonadal tissue was immunoreactivity positive to inhibin and vimentin, respectively (Figure 2), which indicated the presence of Leydig cells. Karyotype analysis of the patient confirmed a 46,XX karyotype and FISH analysis was negative for the SRY gene (Figure 3). Molecular analysis revealed locus deletions at SY84, SY86, SY127, SY134, SY254, and SY255 within the AZF sequence on chromosome Y, with the absence of the $S R Y$ gene (Figure 4). Sequencing of the coding regions and exon/intron boundaries of the RSPO1, DAX1,SOX9, SOX3, SOX10, ROCK1, and DMRT genes detected no mutations. No copy number variation in the whole genome sequence was found. In particular, there was no variation in copy number between positions $64000 \mathrm{~kb}$ and $72000 \mathrm{~kb}$ of chromosome 17q24.2-25.1. Duplication of this region, which codes for $S O X 9$, can trigger sex reversal (Figure 5).

\section{Discussion}

46, XX testicular DSD is a rare form of sex reversal in infertile men, which was first described by la Chapelle et al. in 1964 with a frequency of 1:20,000 of newborn males [1]. Most males have normal phenotypes at birth and are usually diagnosed in adolescence because of delayed puberty, gynecomastia, or infertility. Moreover, some XX males have hypospadias, cryptorchidism, or more severe genital ambiguity. However, all 46,XX males are infertile because of the absence of the azoospermia factor region in the long arm of the Y chromosome. 46, $\mathrm{XX}$ males can be classified into two subgroups, SRYpositive and $S R Y$-negative, according to the presence or absence of the SRY gene, which is located in the Y chromosome and regulates testicular differentiation [10]. Patients with $S R Y$-positive, which always translocates to the $\mathrm{X}$ chromosome or to an autosome, are usually more likely to have a normal male phenotype at birth and are 


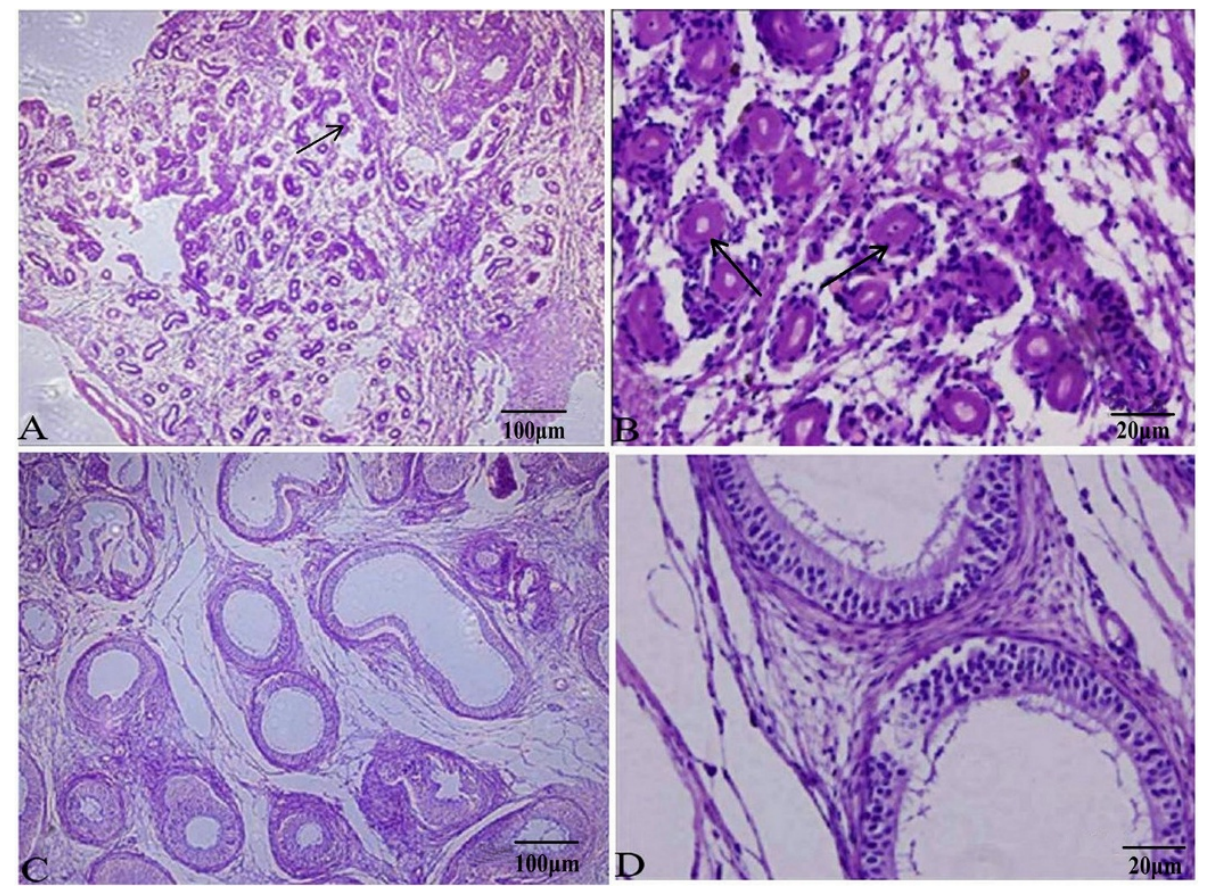

Figure 1 Histological examination of gonadal tissue by HE staining under light microscopy. The results of gonadal biopsy showed the appearance of hyalinization of the seminiferous tubules, but without evidence of spermatogenic cells. (A) and (B) are testis tissue; (C) and (D) are epididymis tissue. The black arrows show hyalinization of seminiferous tubules in (A) and (B).

referred for infertility treatment after puberty. SRYnegative patients include those with ovotesticular-DSD, which is characterized by the presence of testicular and ovarian tissue in the same individual. Testicular-DSD is characterized by full development of both gonads as testes without evidence of ovarian tissue [13].
The mechanisms of testicular tissue induction in SRYnegative patients remain unknown, although several hypotheses have been proposed, as follows: (1) hidden gonadal mosaicism for SRY; (2) mutations in some autosomal or X-linked genes that repress the male pathway can result in de-repression of the male pathway in XX

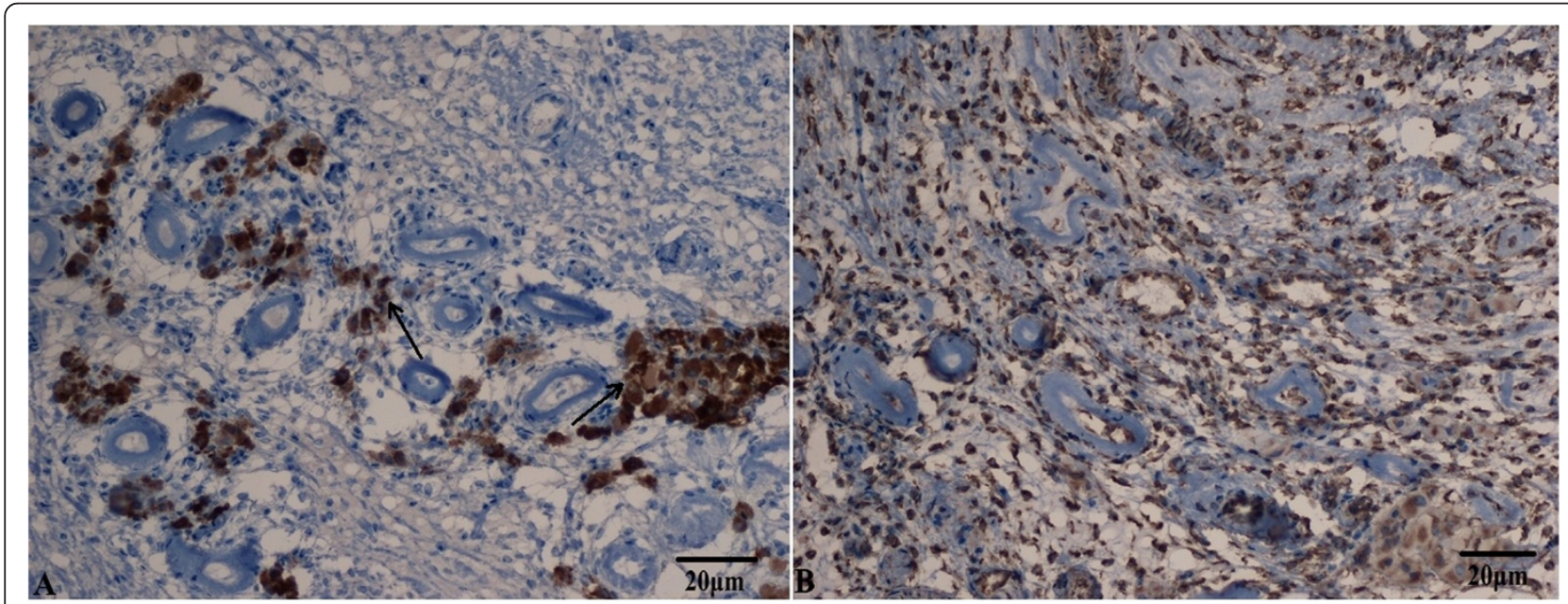

Figure 2 Immunohistochemical staining of inhibin and vimentin was observed by light microscopy. Immunohistochemical analysis also confirmed the gonadal tissue had positive immunoreactivity to inhibin (A) and vimentin (B), which indicated the presence of Leydig cells. The black arrows in (A) indicated that the tissue was positive for inhibin by immunohistochemical staining. 


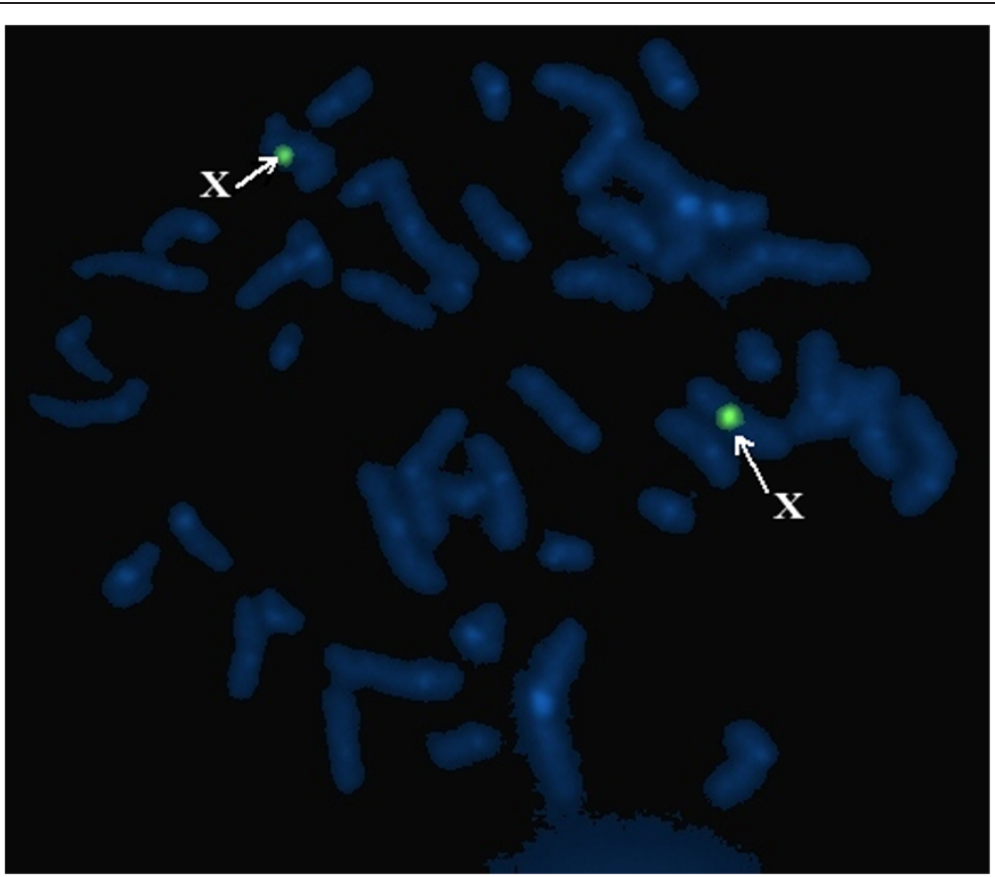

Figure $3 \mathrm{FISH}$ was used to analysis of metaphase chromosomes of a second case using the LSI SRY (orange) / CEP X (green) probes. FISH showed the absence of the SRY gene in our patient, while there were two green signals of the $X$ chromosome (white arrows).

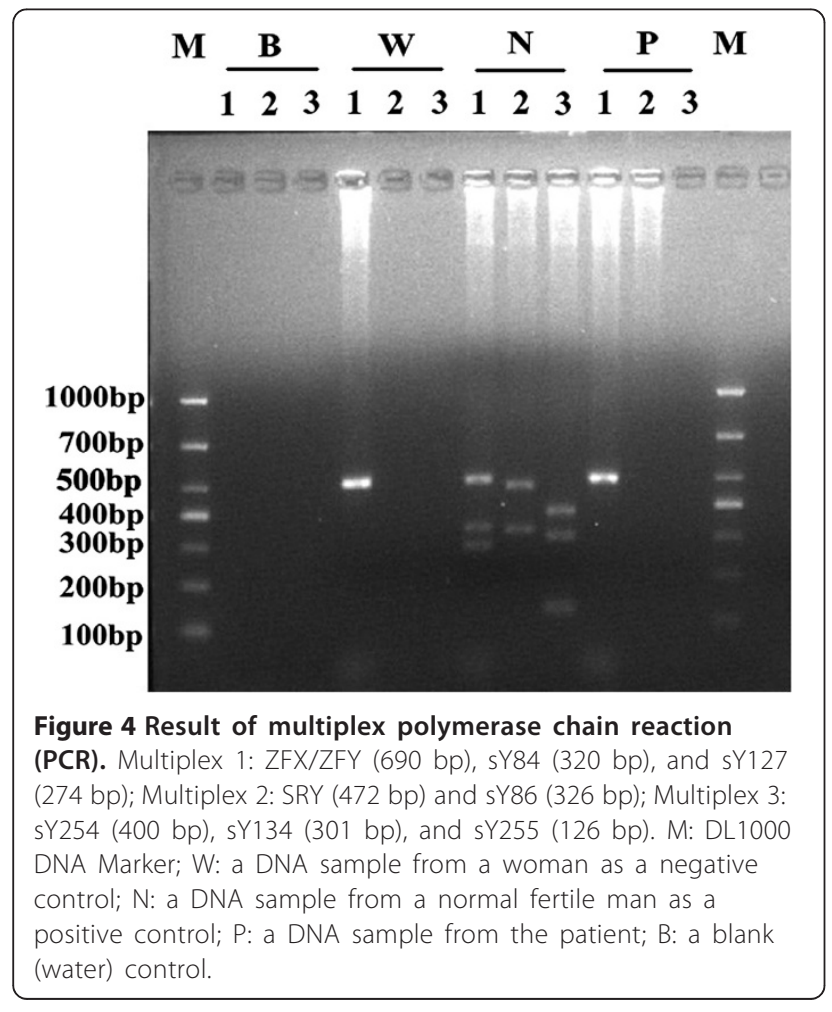

gonads; and (3) altered expression of other sex determining genes downstream of the SRY.

True hermaphroditism (TH), also known as ovotesticularDSD, is a rare form of intersexuality characterized by the presence of testicular and ovarian tissue in the same individual. Genetic heterogeneity has been proposed as a cause of dual gonadal development in some cases and recently, hidden mosaicism was reported to cause $\mathrm{TH}$ in some $S R Y$-negative 46,XX patients [14]. However, Domenice et al. [15] reported the absence of the SRY sequence in DNA from blood samples of all true hermaphrodites and in testicular and ovarian tissues of a 46,XX true hermaphrodite case and a 46,XX male with ambiguous genitalia, which indicated that cryptic SRY mosaicism in gonadal tissues is not the usual mechanism responsible for testicular development in patients with 46,XX true hermaphroditism.

$\mathrm{R}$-Spondin1 (RSPO1) is a novel regulator of ovary development through the up-regulation of the Wnt $/ \beta$ catenin signaling pathway to oppose testis formation $[16,17]$. Loss-of-function mutations in human RSPO1 lead to reduced $\beta$-catenin protein and WNT4 mRNA levels, consistent with downregulation of ovarian pathways, which cause testicular differentiation in 46,XX females [18]. 


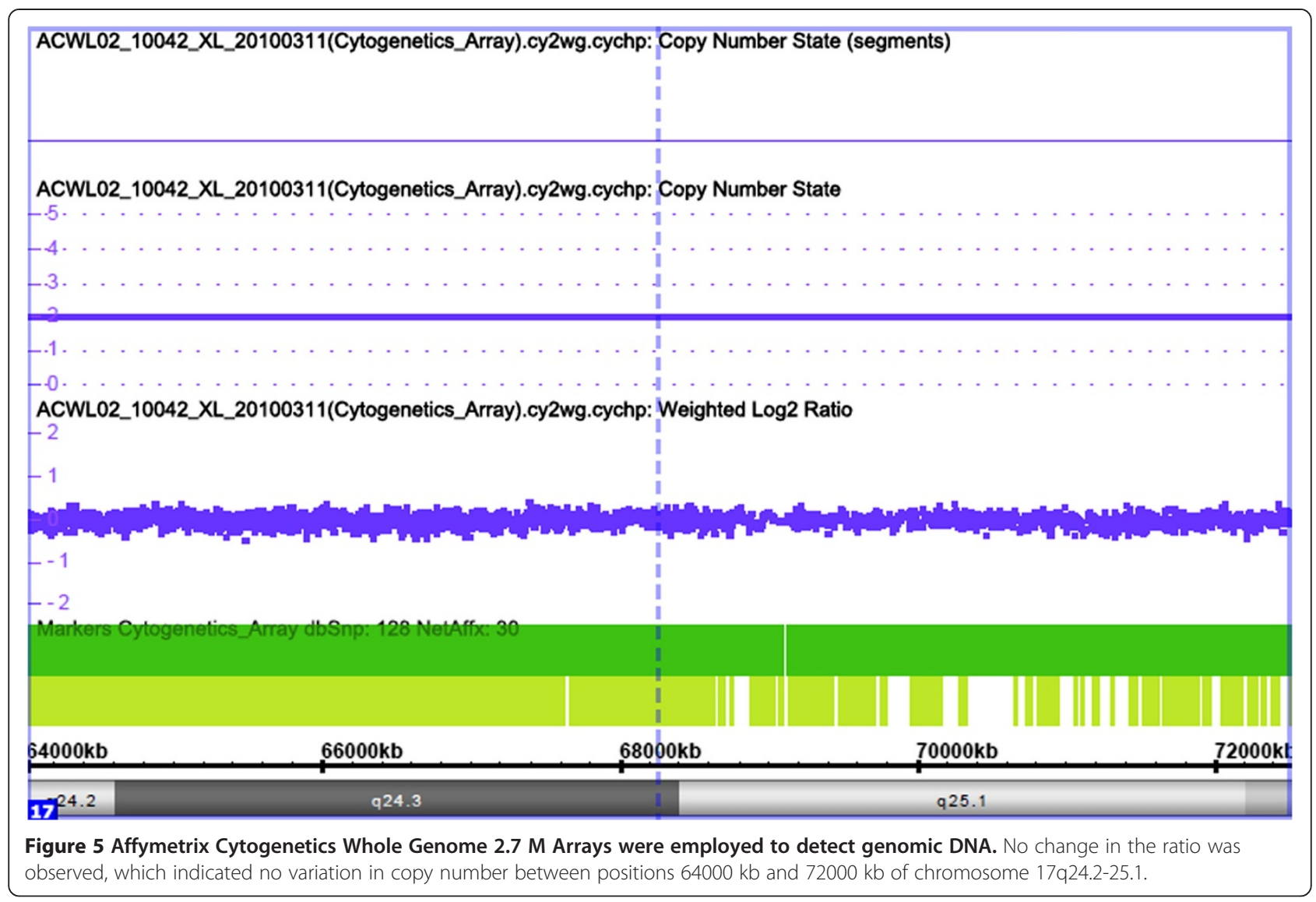

Previous reports have identified gene dysregulation in 46,XX SRY-negative DSD. The SRY-box 9 (SOX9) gene is a widely expressed transcription factor that plays several relevant functions during development and essential for testes differentiation, which is considered to be the direct target gene of the SRY [19]. The essential role of SOX9 in male gonadal development was initially described in mice and subsequent reports stated that SOX9 duplications were a relevant cause of $S R Y$-negative XX sex reversal in dogs [20]. SOX9 duplication was reported for the first time in Korea in a case involving a 4.2-yearold SRY-negative 46,XX boy with complete sex reversal, which indicated that SOX9 duplication was a rare cause of 46,XX testicular DSD in humans [21]. The genomic domain regulating SOX9 expression spans more than $1 \mathrm{Mb}$ upstream of SOX9 [11]. Benko et al. [22] revealed that a non-coding regulatory region located far upstream of the SOX9 promoter was critical for gonadal SOX9 expression and subsequent normal sexual development and copy number variations were the genetic basis of isolated 46,XX testicular DSD of variable severity. Moreover, the minimum critical region associated with gonadal development, about a 67-kb region located 584-517 kb upstream of $S O X 9$, was confirmed to induce $S O X 9$ overexpression in female-to-male sex reversal [11].
Regulatory elements in the duplication region might enhance SOX9 expression through complex mechanisms. It has been suggested that changes in SOX9 expression resulting from disruptions in some regions upstream of SOX9 could be important in 46,XX testicular disorder of sexual development. However, other groups have suggested that duplication in the region of $17 \mathrm{q}$ that contains SOX9 is not a common cause of testis development in subjects with $S R Y$-negative 46,XX testicular or ovotesticular DSD [23].

Consistent with SOX9, the DAX1 gene might also function downstream of the $S R Y$ gene in the sex-determination pathway. Overexpression of the $D A X 1$ gene could cause female-to-male sex reversal [24]. ROCK1 (Rho-associated, coiled-coil protein kinase 1) phosphorylates and activates SOX9 in Sertoli cells to initiate testes formation [13]. SOX3 was recently shown to upregulate $S O X 9$ expression via a similar mechanism to $S R Y$ and modulate $\mathrm{XX}$ male sex reversal in humans through gain-of-function mutations mediated by genomic rearrangements around $S O X 3$, possibly leading to its altered regulation [25-27]. Overexpression of the SOX10 gene at 22q13 might be the cause of sex reversal [28].

However, the above mechanisms were not applicable in this case, as any hidden gonadal mosaicism for $S R Y$ or 
mutations to autosomal or sex-linked genes that repress the male pathway and alter expression of other sex determining genes downstream of SRY were found in our case. These findings suggest that other unidentified genetic or environmental factors play significant roles in the regulation of sex determination and differentiation.

\section{Conclusions}

46,XX SRY-negative individuals with complete masculinization are rare and usually exhibit phenotypic differences. Our patient had incomplete masculinization, which was characterized by microorchidism and mild bilateral gynecomastia, and was diagnosed with abnormal gender characteristics. His T level was low and levels of FSH and LH were elevated. Furthermore, we detected locus deletions at SY84, SY86, SY127, SY134, SY254, and SY255 within the AZF sequence on chromosome $\mathrm{Y}$, with the absence of the $S R Y$ gene. Further studies are needed to explain the mechanisms of 46,XX testicular disorder of sexual development characterized by the described phenotype with a lack of spermatogenesis.

\section{Consent}

Written informed consent was obtained from the parent of the patient for publication of this case report and any accompanying images. A copy of the written consent is available for review by the Editor of this journal.

\section{Abbreviations \\ DSD: Disorder of sex development; SRY: Sex-determining region Y; TDF: Testis determining factor; FSH: Follicle-stimulating Hormone; LH: Luteinizing Hormone; E2: Estradiol; PRL: Prolactin; T: Testosterone; PCR: Polymerase Chain Reaction; FISH: Fluorescent in situ hybridization; TH: True hermaphroditism; Rspo1: R-Spondin 1; SOX9: SRY-box 9; ROCK1: Rho- associated, coiled-coil protein kinase 1.}

\section{Competing interests}

The authors declare that they have no competing interests.

\section{Authors' contributions}

TFL, QYW, XYX and YCS conceived and designed the experiments. WWL, CZ, QZ, WJJ and YXC performed the experiments. YCS and QYW analyzed the data. TFL and XYX wrote the paper. All authors read and approved the final manuscript.

\section{Acknowledgments}

This work was supported by Natural Science Foundation of Jiangsu Province (BK2011660 and BK2012601), Key Foundation of Jiangsu Science and Technology Bureau (BM2013058) and Nature Science Foundation of China (81170611).

Received: 5 September 2014 Accepted: 19 December 2014 Published: 22 December 2014

\section{References}

1. Delachapelle A, Hortling H, Niemi M, Wennström J: XX sex chromosomes in a human male. First case. Acta Med Scand 1964, 175(Suppl 412):25-28.

2. Abbas NE, Toublanc JE, Boucekkine C, Toublanc M, Affara NA, Job J-C, Fellous M: A possible common origin of "Y-negative" human XX males and XX true hermaphrodites. Hum Genet 1990, 84(4):356-360.

3. Boucekkine C, Toublanc J, Abbas N, Chaabouni S, Ouahid S, Semrouni M, Jaubert F, Toublanc M, McElreavey K, Vilain E: Clinical and anatomical spectrum in XX sex reversed patients. Relationship to the presence of $Y$ specific DNA-sequences. Clin Endocrinol 1994, 40(6):733-742.
4. McElreavey K, Rappaport R, Vilain E, Abbas N, Richaud F, Lortat-Jacob S, Berger R, LeConiat M, Boucekkine C, Kucheria K: A minority of 46, XX true hermaphrodites are positive for the Y-DNA sequence including SRY. Hum Genet 1992, 90(1-2):121-125.

5. Anık A, Çatlı G, Abacı A, Böber E: 46, XX male disorder of sexual development: a case report. J Clin Res Pediatr Endocrinol 2013, 5(4):258-260.

6. Jain M, V V, Chaudhary I, Halder A: The Sertoli Cell Only Syndrome and Glaucoma in a Sex-Determining Region Y (SRY) Positive XX Infertile Male. J Clin Diagn Res 2013, 7(7):1457-1459.

7. Vorona E, Zitzmann M, Gromoll J, Schuring AN, Nieschlag E: Clinical, endocrinological, and epigenetic features of the 46, XX male syndrome, compared with 47, XXY Klinefelter patients. J Clin Endocrinol Metab 2007, 92(9):3458-3465.

8. Rizvi AA: 46, XX man with SRY gene translocation: cytogenetic characteristics, clinical features and management. Am J Med Sci 2008, 335(4):307-309.

9. Eghbali M, Sadeghi MR, Lakpour N, Edalatkhah $H$, Zeraati $H$, Soltanghoraee $H$, Akhondi MM, Hashemi SB, Modarressi MH: Molecular analysis of testis biopsy and semen pellet as complementary methods with histopathological analysis of testis in non-obstructive azoospermia. J Assist Reprod Genet 2014, 31(6):707-715.

10. Wu QY, Li N, Li WW, Li TF, Zhang C, Cui YX, Xia XY, Zhai JS: Clinical, molecular and cytogenetic analysis of $46, X X$ testicular disorder of sex development with SRY-positive. BMC Urol 2014, 14(1):70.

11. Xiao B, Ji X, Xing Y, Chen YW, Tao J: A rare case of $46, X X$ SRY-negative male with approximately $74-\mathrm{kb}$ duplication in a region upstream of SOX9. Eur J Med Genet 2013, 56(12):695-698.

12. Rohrich RJ, Ha RY, Kenkel JM, Adams WP Jr: Classification and management of gynecomastia: defining the role of ultrasoundassisted liposuction. Plast Reconstr Surg 2003, 111(2):909-923.

13. Mizuno K, Kojima $Y$, Kamisawa H, Moritoki $Y$, Nishio H, Kohri K, Hayashi Y: Gene expression profile during testicular development in patients with SRY-negative 46,XX testicular disorder of sex development. Urology 2013, 82(6):1453. e1-e7.

14. Nieto K, Peña R, Palma I, Dorantes LM, Eraña $L$, Alvarez $R$, García-Cavazos $R$, Kofman-Alfaro S, Queipo G: 45, X/47, XXX/47, XX, del (Y)(p?)/46, XX mosaicism causing true hermaphroditism. Am J Med Genet A 2004, 130A(3):311-314.

15. Domenice S, Nishi MY, Billerbeck AE, Carvalho FM, Frade EM, Latronico AC, Arnhold IJ, Mendonca BB: Molecular analysis of SRY gene in Brazilian 46, $X X$ sex reversed patients: absence of SRY sequence in gonadal tissue. Med Sci Monit 2001, 7(2):238-241.

16. De Lau WB, Snel B, Clevers HC: The R-spondin protein family. Genome Biol 2012, 13(3):242.

17. Smith CA, Shoemaker CM, Roeszler KN, Queen J, Crews D, Sinclair AH: Cloning and expression of R-Spondin 1 in different vertebrates suggests a conserved role in ovarian development. BMC Dev Biol 2008, 8(1):72.

18. Tomaselli S, Megiorni F, Lin L, Mazzilli MC, Gerrelli D, Majore S, Grammatico P, Achermann JC: Human RSPO1/R-spondin1 is expressed during early ovary development and augments $\beta$-catenin signaling. PLOS One 2011, 6(1):e16366

19. Vetro A, Ciccone R, Giorda R, Patricelli MG, Della Mina E, Forlino A, Zuffardi O: XX males SRY negative: a confirmed cause of infertility. J Med Genet 2011, 48(10):710-712.

20. Rossi E, Radi O, De Lorenzi L, Vetro A, Groppetti D, Bigliardi E, Luvoni GC, Rota A, Camerino G, Zuffardi O: Sox9 duplications are a relevant cause of Sry-negative XX sex reversal dogs. PLoS One 2014, 9(7):e101244.

21. Lee GM, Ko JM, Shin CH, Yang SW: A Korean boy with 46, XX testicular disorder of sex development caused by SOX9 duplication. Ann Pediatr Endocrinol Metab 2014, 19(2):108-112.

22. Benko S, Gordon CT, Mallet D, Sreenivasan R, Thauvin-Robinet C, Brendehaug A, Thomas S, Bruland O, David M, Nicolino M, Labalme A, Sanlaville D, Callier P, MaIan V, Huet F, Molven A, Dijoud F, Munnich A, Faivre L, Amiel J, Harley V, Houge $\mathrm{G}$, Morel $\mathrm{Y}$, Lyonnet S: Disruption of a long distance regulatory region upstream of SOX9 in isolated disorders of sex development. J Med Genet 2011, 48(12):825-830.

23. Temel SG, Cangul H: Duplication of SOX9 is not a common cause of 46, XX testicular or 46, XX ovotesticular DSD. J Pediatr Endocrinol Metab 2013, 26(1-2):191. 
24. Sukumaran A, Desmangles JC, Gartner LA, Buchlis J: Duplication of dosage sensitive sex reversal area in a $46, X Y$ patient with normal sex determining region of $Y$ causing complete sex reversal. J Pediatr Endocrinol Metab 2013, 26(7-8):775-779.

25. Moalem S, Babul-Hirji R, Stavropolous DJ, Wherrett D, Bägli DJ, Thomas P, Chitayat D: XX male sex reversal with genital abnormalities associated with a de novo SOX3 gene duplication. Am J Med Genet A 2012, $158 \mathrm{~A}(7): 1759-1764$.

26. Sutton E, Hughes J, White S, Sekido R, Tan J, Arboleda V, Rogers N, Knower K, Rowley L, Eyre H, Rizzoti K, McAninch D, Goncalves J, Slee J, Turbitt E, Bruno D, Bengtsson H, Harley V, Vilain E, Sinclair A, Lovell-Badge R, Thomas P: Identification of SOX3 as an XX male sex reversal gene in mice and humans. J Clin Invest 2011, 121(1):328-341.

27. Laronda MM, Jameson JL: Sox3 functions in a cell-autonomous manner to regulate spermatogonial differentiation in mice. Endocrinology 2011, 152(4):1606-1615.

28. Polanco JC, Wilhelm D, Davidson $T L$, Knight D, Koopman P: Sox 10 gain-of-function causes XX sex reversal in mice: implications for human 22q-linked disorders of sex development. Hum Mol Genet 2010, 19(3):506-516.

doi:10.1186/1471-2490-14-104

Cite this article as: Li et al:: 46,XX testicular disorder of sexual development with $S R Y$-negative caused by some unidentified mechanisms: a case report and review of the literature. BMC Urology 2014 14:104.

\section{Submit your next manuscript to BioMed Central and take full advantage of:}

- Convenient online submission

- Thorough peer review

- No space constraints or color figure charges

- Immediate publication on acceptance

- Inclusion in PubMed, CAS, Scopus and Google Scholar

- Research which is freely available for redistribution 